\title{
Esophagus and Esophagogastric Junction Cancer pT1b TNM Finding v8
}

National Cancer Institute

\section{Source}

National Cancer Institute. Esophagus and Esophagogastric Junction Cancer pT 1b TNM

Finding v8. NCI Thesaurus. Code C133379.

Esophagus and esophagogastric junction cancer with tumor invading the submucosa.

(from AJCC 8th Ed.) 